\title{
Key components of working capital management: Investment performance in Malaysia
}

\author{
Pui-Yan Loo a and Wei-Theng Lau ${ }^{a *}$
}

${ }^{a}$ Universiti Putra Malaysia, Malaysia

\begin{tabular}{l}
\hline C H R O N I C L E \\
\hline Article history: \\
Received: June 12, 2019 \\
Received in revised format: June \\
292019 \\
Accepted: July 6, 2019 \\
Available online: \\
July 6, 2019 \\
\hline Keywords: \\
Working capital management \\
Liquidity position \\
Investment returns \\
Cash conversion cycle \\
Firm-level panel data
\end{tabular}

\section{Introduction}

Working capital refers to the short-term assets used or needed by a firm to support its usual business operations. Net working capital is generally known as surplus of current assets over current liabilities. It is thus a consensus to understand that working capital is seldom expected to create much direct value to the firm such as being generated by the long-term investments. However, an efficient management of working capital could have significant implications for business investors. A recent study of PricewaterhouseCoopers Malaysia by Gunaratnam and Seela (2019) on over 400 firms listed on Bursa Malaysia in 2017 reveals that there was a total of RM 110 billion cash not properly utilized, and the net working capital had been at its 4-year high of 56 days. Inefficient management of working capital would cause a waste of cash assets that should be allocated for better uses in generating returns. Nevertheless, it is also important to maintain a sufficient level of cash for payments of supplies, short-term debt, opportunities for investment and necessities to meet market demand in a timely manner. A longer cash conversion cycle might also imply higher expected sales and thus profitability. This is the main reason as to why

\begin{abstract}
This study attempts to examine the role of working capital management components on four commons which are distinctive dimensions of business investment performance in Malaysia. The analysis covers 431 listed companies for the period 2000-2017 post the Asian financial crisis. The four
performance indicators are return on assets (to proxy book return on overall business assets), return on equity (to proxy book return on shareholders' fund), Tobin's Q (to proxy firm valuation) and stock performance (to proxy real shareholder wealth). Our results indicate that working capital components of receivables collection period, inventory conversion period, payables deferral period, overall cash conversion cycle, current ratio, quick ratio, and cash ratio have generally exhibited important relationships with investment performance before and after the 2007-2008 subprime
crisis. We would like to highlight the very robust negative effect of receivables collection period and cash conversion cycle. In addition, it is worth noting the distinctive roles of cash conversion cycle components and working capital liquidity ratios. While overly high liquidity position is usushow that a high liquid position is favourable if the impact of panel data analysis consistently sidered. Hence, it is crucial for managers to prioritize the importance of working capital requirements to enhance the value of investors.
\end{abstract}

E-mail address: 1wtheng@upm.edu.my (W.-T. Lau) 
making decisions for working capital could be somewhat challenging. Using the data post the Asian financial crisis that occurred in the late 1990's, we wish to investigate the role of working capital management on a few common indicators of investment performance of Malaysian listed firms.

Empirical findings related to working capital has been extensive. The existing literature has agreed with the importance of working capital management in terms of liquidity, profitability, firm's value and performance of a company, in both positive and negative ways. It depicts the survival and performance of many forms of businesses all over the world. It is especially important during the bad times of business (Enqvist et al., 2014), recovery of business or times when capital is less accessible (Le, 2019; Salehi et al., 2019). In their interview and surveyed results, Ramiah et al. (2014) find that more than half of the practitioners alter the working capital practices during crisis by focusing more on cash preservation. Thus, we are also interested whether the role of working capital management would significantly change before and after the 2007-2008 subprime crisis. A short cash conversion cycle can help a business generate more cash. There is also lower need for borrowing to fund working capital. In the US, Shin and Soenen (1998) find that there is a strong negative relationship between the cash conversion cycle and corporate profitability for the 1975-1994 period. Aktas et al. (2015) suggest that an optimal level of working capital policy exists, and that working capital investment could improve stock and operating performance. Cutting unnecessary investment in net operating working capital can help to improve stock performance and encourage corporate investment. The study period is from 1982 to 2011 for a sample of US firms. It is consistent with the findings by Kieschnick et al. (2013) in assessing net working capital for the period of 1990-2006. Using industry specific analysis, Ganesan (2007) finds a negative correlation between working capital management (cash conversion cycle components) and operating profitability in the US telecommunication equipment industry between the years 2001 and 2007. In contrast, Hill et al. (2012) support that trade receivables can positively affect shareholder returns in a sample of non-financial, nonutility firms for the period 1971-2006. A higher value of receivables is most likely related to higher operating and contracting costs.

In Europe, Deloof (2003) suggests that gross operating income is negatively related to days in receivables, inventories and payables of Belgian firms. Lazaridis and Tryfonidis (2006) also discover a negative relationship between cash conversion cycle components and gross operating profit on business assets in the Athens Stock Exchange for observations from 2001 to 2004. Enqvist et al. (2014) suggest that efficient inventory and accounts receivables management have become more vital during economic downturns. By studying the net trade cycle or cash conversion cycle in the UK from 2001 to 2007, BañosCaballero et al. (2014) further suggest that the optimal level of working capital is important in affecting firm's value. In Asia, Wang (2002) observes that a shorter cash conversion cycle is important to improve operating performance by studying the Japanese and Taiwanese firms during 1985-1996. Nobanee et al. (2011) later propose similar results for Japanese firms for the period 1990-2004. In their study in Australia, Bhakoo et al. (2012) highlight the importance of inventory management as failing to control inventories could lead to decline in profitability and firms' survival chances. In Saudi Arabia, Eljelly (2004) finds that firm's current ratio and cash conversion cycle exhibit a significant inverse relationship with profitability. This relationship is more prevalent if a firm has a high current ratio and long cash conversion cycle. In recent years, there have also been related studies in the developing markets. By testing the cash conversion cycle components, Bammeri and Dehani (2013) only find a weak positive relationship between the inventory conversion cycle and stock return of listed companies in the Tehran Stock Exchange between the years 2002-2011. Nastiti et al. (2019) find a positive relationship between cash conversion cycle and book return on assets for manufacturing firms in Indonesia between 2010 and 2017. Abuzayed (2012) finds that longer cash conversion cycle has a positive impact on profitability in Amman Stock Exchange during the years between 2000 and 2008. This may suggest that more profitable firms are less motivated to manage the working capital. It may also mean that the markets do not penalize firms for incompetent working capital management. There are, of course, empirical evidence found on negative relationship. For example, Padachi (2006) finds that receivables collection period and inventory 
conversion period indicate negative relationship with return on assets in the Mauritian small manufacturing firms during 1998-2003. Raheman and Nasr (2007) also observe a negative association between cash conversion cycle components and operating profit on business assets in the Karachi Stock Exchange during 1999-2004. Such finding is consistent with the study by Ray (2012) in the Indian market for a period of 14 years up to 2010 on net operating profit. Akindele and Odusina (2015) further suggest that cash conversion cycle has an inverse relationship towards profitability measured by return on assets in the Nigerian market for the years 2005-2011. The same negative relationship is found by Ghodrati and Ghanbari (2014) in Tehran Stock Exchange between cash conversion cycle and operating profitability for the study period of 2008-2012. In the Istanbul Stock Exchange, Şamiloğlu and Akgün (2016) find that cash conversion cycle and receivables collection period are negatively related to return on assets, but positively related to return on equity for manufacturing firms. Singhania and Mehta (2017) further suggest that a non-linear relationship exists between cash conversion cycle and return on assets in several emerging Asian countries. There have also been studies in the Malaysian market prior to the subprime crisis. Mohamad and Saad (2010) suggest a negative relationship between cash conversion cycle and firm performance for the study period of 2003-2007. Meanwhile, Wasiuzzaman (2015) finds that working capital management efficiency is crucial to firm value during 1999-2008. A decrease in working capital investment, measured by using the sum of accounts receivables and inventories minus account payables, would lead to higher firm value especially for the financially constrained firms. Such a finding is consistent with the claim by Le (2019) in the Vietnamese market.

Our literature review indicates that most current studies of working capital focus on profitability and to a lesser extent on firm value, especially in the developing markets and Malaysia. In addition to covering more investment performance measures, this study intends to highlight the fundamental differences between the cash conversion cycles components and the liquidity ratios. The cash conversion cycle is about the management of net operating working capital. While current ratio, quick ratio and cash ratio are commonly known as the "working capital ratios", an overly high ratio is usually seen as a bad sign in terms of working capital efficiency. Nevertheless, we opine that having a good liquidity position is important for investment performance. It is therefore of our interest to see if the liquidity ratios would have a positive impact on performance if the cash conversion cycle is well considered. This study could also complement the findings in Malaysia by Mohamad and Saad (2010) and Wasiuzzaman (2015) by employing a longer time span of 17 years, encompassing a more balanced period before and after the outbreak of the subprime crisis, with a larger sample of over 400 firms and a wider scope of variables.

\section{Data and methodology}

This study aims to examine the relationship between the working capital management and investment returns for public-listed firms on the Bursa Malaysia during the period 2001-2017. The main hypothesis is thus that there is a significant relationship between working capital management and investment returns of listed firms in Bursa Malaysia. Working capital management variables are proxied by the cash conversion cycle components (see, for e.g., Shin \& Soenen, 1998; Mohamad \& Saad, 2010; Ray, 2012; Bammeri \& Dehani, 2013; Baños-Caballero et al., 2014; Akindele \& Odusina, 2015; Nastiti et al., 2019) and the commonly adopted liquidity ratios (current ratio, quick ratio and cash ratio). In order to capture more dimensions of returns and to complement the current literature for more comprehensive comparisons, our measures of investment performance cover return on assets (see Wang, 2002; Enqvist et al, 2014; Akindele \& Odusina, 2015; Nguyen et al., 2016; Nastiti et al., 2019), return on equity (see Wang, 2002; Nguyen et al., 2016; Şamiloğlu \& Akgün, 2016), Tobin's Q (see Mohamad \& Saad, 2010; BañosCaballero et al., 2014; Wasiuzzaman, 2015) and stock performance (see Brush et al., 2000; Hill et al, 2012; Bammeri \& Dehani, 2013; Kieschnick et al., 2013; Aktas et al., 2015). Share price data are sourced from the Bursa Malaysia while the firm-level financial data are obtained from the audited financial statements. Due to the unique nature of trading and differences in the definition of working capital, firms in the financial sector such as banks, insurance and investment are excluded from the study. Unbalanced annual financial data of the 431 active listed companies of all industries except finance are thus collected 
from Datastream with about 5500 firm-year observations for the said period after the top and bottom one percent of data are trimmed. These data are collected for the purpose of testing the relationship below:

$$
i r_{i t}=\beta_{0}+\beta_{1 r c p}+\beta_{2 i} i c p_{i t}+\beta_{3} p d p_{i t}+\beta_{4 c c c} c_{i t}+\beta_{5} c u r_{i t}+\beta_{6 q r_{i t}}+\beta_{7 c a r_{i t}}+\beta_{n} \text { controls }_{i t}+u_{i t}+\varepsilon_{i t}
$$

where $i r_{i t}$ is the investment return for firm $i$ at time $t$ proxied by return on assets, return on equity, Tobin's $Q$ and annual stock performance. Return on assets is net income divided by total assets; return on equity is net income divided by shareholder's equity; Tobin's $Q$ is the ratio of market value of assets to the replacement cost of assets (or the book value of assets); and stock performance is the natural logarithm of stock prices of firms. Return on assets is a profitability measures to represent the book return on overall business assets. Whereas return on equity is used to proxy the book return on shareholders' fund. Tobin's Q is to reflect firm's market valuation and stock performance is to measure real shareholder wealth. The studied working capital variables are as follows:

$r c p_{i t}=$ receivables collection period, estimated by (account receivables / revenue $\times 365$ days), $i c p_{i t}=$ inventory conversion period, estimated by (inventories / cost of goods sold $\times 365$ days),

$p d p_{i t}=$ payables deferral period, estimated by (account payables / cost of goods sold $\times 365$ days), $c c c_{i t}=$ cash conversion cycle, estimated by $(\mathrm{rcp}+\mathrm{icp}-\mathrm{pdp})$, cur $_{i t}=$ current ratio, estimated by the ratio of current asset to current liabilities, $q r_{i t}=$ quick ratio, estimated by the ratio of current assets (net inventories) to current liabilities, $c a r_{i t}=$ cash ratio, estimated by the ratio of cash assets (net inventories $\&$ receivables) to current liabilities.

Receivables collection period is the average length of time (in days) needed to receive cash from sales. Inventory conversion period reflects the average number of days taken to turn the inventories into sales. Short receivables collection and inventory conversion periods are usually preferred as they imply efficiency in cash flow management. Payables deferral period indicates the average number of days taken to pay the suppliers. Current ratio, quick ratio and cash ratio, also known as working capital liquidity ratios, reflect firm's liquidity health. Cash ratio is the most conservative indicator among the three as it measures the ability to pay off current liabilities without considering the amount of inventories and accounts receivables, which are usually substantial in current assets. The subscripts of $i$ and $t$ denote firm $i$ for time period $t$. $\varepsilon_{i t}$ is the error term of the model and $u_{i t}$ is firm-specific factor. Some common important control variables (controls $\mathrm{it}_{\mathrm{it}}$ ) of firm size, sales growth and book-to-market ratio are also employed (see, for e.g., Brush et al., 2000; Garcia-Teruel \& Martinez-Solano, 2007; Abuzayed, 2012; Hill et al., 2012; Aktas et al., 2015; Wasiuzzaman, 2015; Singhania \& Mehta, 2017; Le, 2019; Nastiti et al., 2019).

$$
i r_{i t}=\beta_{0}+\beta_{1} r c p_{i t}+\beta_{2} i c p_{i t}+\beta_{3} p d p_{i t}+\beta_{4} c c c_{i t}+\beta_{5} c u r_{i t}+\beta_{6} q r_{i t}+\beta_{7} c a r_{i t}+\beta_{8} s i z e_{i t}+\beta_{9 g} \text { rowth }_{i t}+\beta_{10} b t m_{i t}+u_{i t}+\varepsilon_{i t}
$$

where size $_{i t}$ is firm size, estimated by the natural logarithm of total assets; growth ${ }_{i t}$ is annual sales growth; and $b_{t m}$ it is book-to-market of equity. Low book-to-equity ratio usually represents value stock and high ratio usually implies high growth potential. Due to the multicollinearity problems with high variance inflation factors found between cash conversion cycle and the group of receivables collection period, inventory conversion period and payables deferral period; and among current ratio, quick ratio and cash ratio, the regressions are performed separately for these variables.

$$
\begin{aligned}
& i r_{i t}=\beta_{0}+\beta_{1 r c p_{i t}}+\beta_{2 i c p_{i t}}+\beta_{3} p d p_{i t}+\beta_{5} \text { cur }_{i t}+\beta_{8 \text { size }_{i t}}+\beta_{9 \text { growth }_{i t}}+\beta_{10} b_{t m_{i t}}+u_{i t}+\varepsilon_{i t} \\
& i_{i t}=\beta_{0}+\beta_{4 c c c}{ }_{i t}+\beta_{5} \text { cur }_{i t}+\beta_{8 s_{i z}} \text { sit }+\beta_{9 \text { growth }}+\beta_{10}+\beta_{t m}{ }_{i t}+u_{i t}+\varepsilon_{i t} \text {, } \\
& i r_{i t}=\beta_{0}+\beta_{4 c c c}{ }_{i t}+\beta_{6} q r_{i t}+\beta_{8 \text { size }_{i t}}+\beta_{9 \text { growth }_{i t}}+\beta_{10} \text { btm }_{i t}+u_{i t}+\varepsilon_{i t},
\end{aligned}
$$

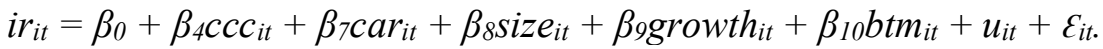

To ensure the robustness of the results which could be affected by possible heteroscedasticity and autocorrelation, we also report the findings from firm's fixed effects regressions, regressions with robust 
standard errors (SE) clustered by firm and by time. Table 1 presents some descriptive statistics of the variables used in the study.

Table 1

Descriptive statistics

\begin{tabular}{ccccc}
\hline Variable & Mean & Standard deviation & Minimum & Maximum \\
\hline Return on assets (roa) & 2.659 & 7.111 & -39.35 & 28.53 \\
Return on equity (roe) & 4.923 & 14.23 & -79.34 & 70.23 \\
Tobin's Q & 1.031 & 0.547 & 0.406 & 5.390 \\
Stock performance (stock) & -0.242 & 1.077 & -2.733 & 2.972 \\
Receivables collection period (rcp) & 132.6 & 133.3 & 11 & 1058 \\
Inventory conversion period (icp) & 183.7 & 331.2 & 0 & 3163 \\
Payables deferral period (pdp) & 75.5 & 89.9 & 0 & 832 \\
Cash conversion cycle (ccc) & 214.4 & 310.6 & -259 & 2556 \\
Current ratio (cur) & 2.701 & 3.051 & 0.190 & 26.19 \\
Quick ratio (qr) & 1.996 & 2.586 & 0.120 & 23.53 \\
Cash ratio (car) & 1.132 & 2.215 & 0.020 & 22.66 \\
Firm size (size) & 8.611 & 0.5866 & 7.480 & 10.540 \\
Sales growth (growth) & 8.721 & 34.839 & -72.90 & 260.5 \\
Book-to-market (btm) & 1.491 & 0.9980 & -1.450 & 5.880 \\
\hline
\end{tabular}

\section{Results and discussion}

Basic correlation analysis (not tabulated) reveals that there are strong positive correlations among current ratio, quick ratio and cash ratio, and that the cash conversion cycle has strong correlation with the receivables collection period, inventory conversion period and payable deferral period. High variance inflation factors are also found when they are included within a single equation. Such observations indicate the existence of multicollinearity problems. Hence, these components are separated in the regressions of variables.

\subsection{Working capital management and the book return on assets and return on equity}

Return on assets and return on equity are usually used as the proxies of profitability in the previous studies of working capital management. Return on assets is important to proxy the overall business profitability performance on all assets utilized, whilst return on equity is useful in evaluating the earnings ability of firms for the shareholders' fund in the balance sheet. In this study, we adopt and compare the impacts on both. Table 2 and Table 3 indicate that receivables collection period and cash conversion cycle have stable significant negative relationship with both measures of returns across various estimations. Pooled ordinary least square (OLS), fixed effects model, regressions with robust standard errors clustered by firm and by time are adopted to check for the robustness of relationship in our tests. For instance, an increase of a day in receivables collection period would reduce the return on assets by $0.01275 \%$ and return on equity by $0.01946 \%$ under the pooled OLS estimations. The significance of such negative relationship holds for the rest of the estimations. Inventory conversion period and payables deferral period also indicate negative relationship with returns but with less consistent significance across estimations. It may also imply that less profitable firms pay their bills late. Meanwhile, our tests suggest that liquidity exhibits strong positive relationships with both return measures by considering the cash conversion cycle components in the equations. All current ratio, quick ratio and cash ratio are able to substitute the role for each other in affecting return performance. The results suggest that maintaining a healthy liquidity position in meeting working capital requirements is crucial for promoting positive business return performance. Firm size and sales growth generally exhibit position relationship, implying that large firms with higher sales growth are able to achieve higher returns. Negative book-to-market coefficients also suggest that firms with higher growth prospects tend to outperform. 
Table 2

Impact of working capital management on return on assets (roa)

\begin{tabular}{|c|c|c|c|c|c|c|c|c|}
\hline $\begin{array}{l}\text { Dependent: } \\
\text { roa }\end{array}$ & $\begin{array}{l}\text { Pooled } \\
\text { OLS }\end{array}$ & $\begin{array}{c}\text { Pooled } \\
\text { OLS }\end{array}$ & $\begin{array}{l}\text { Pooled } \\
\text { OLS }\end{array}$ & $\begin{array}{c}\text { Pooled } \\
\text { OLS }\end{array}$ & $\begin{array}{c}\text { Fixed effect } \\
\text { model }\end{array}$ & $\begin{array}{l}\text { SE clustered } \\
\text { (by firm) }\end{array}$ & $\begin{array}{l}\text { SE clustered } \\
\text { (by firm) }\end{array}$ & $\begin{array}{l}\text { SE clustered } \\
\text { (by year) }\end{array}$ \\
\hline \multirow[t]{2}{*}{ rcp } & $-0.01275^{* * *}$ & & & & $-0.00981 * * *$ & $-0.01275^{* * *}$ & & $-0.01275^{* * *}$ \\
\hline & $(0.00086)$ & & & & $(0.00102)$ & $(0.00177)$ & & $(0.00112)$ \\
\hline \multirow[t]{2}{*}{ icp } & -0.00043 & & & & 0.00000 & -0.00043 & & -0.00043 \\
\hline & $(0.00036)$ & & & & $(0.00051)$ & $(0.00062)$ & & $(0.00027)$ \\
\hline \multirow[t]{2}{*}{ pdp } & $-0.00373 * * *$ & & & & -0.00190 & $-0.00373^{*}$ & & $-0.00373 * *$ \\
\hline & $(0.00125)$ & & & & $(0.00141)$ & $(0.00216)$ & & $(0.00149)$ \\
\hline \multirow[t]{2}{*}{$\mathrm{ccc}$} & & $-0.00347 * * *$ & $-0.00278 * * *$ & $-0.00258 * * *$ & & & $-0.00347 * * *$ & \\
\hline & & $(0.00032)$ & $(0.00033)$ & $(0.00033)$ & & & $(0.00062)$ & \\
\hline \multirow[t]{2}{*}{ cur } & $0.4097 * * *$ & $0.4703 * * *$ & & & $0.4233 * * *$ & $0.4097 * * *$ & $0.4703 * * *$ & $0.4097 * * *$ \\
\hline & $(0.0292)$ & $(0.0294)$ & & & $(0.0401)$ & $(0.0659)$ & $(0.0694)$ & $(0.0357)$ \\
\hline \multirow[t]{2}{*}{$\mathrm{qr}$} & & & $0.4579 * * *$ & & & & & \\
\hline & & & $(0.0345)$ & & & & & \\
\hline \multirow[t]{2}{*}{ car } & & & & $0.4542 * * *$ & & & & \\
\hline & & & & $(0.0396)$ & & & & \\
\hline \multirow[t]{2}{*}{ size } & $2.4098 * * *$ & $2.5925 * * *$ & $2.5263 * * *$ & $2.3072 * * *$ & $1.7620 * * *$ & $2.4098 * * *$ & $2.5925^{* * *}$ & $2.4098 * * *$ \\
\hline & $(0.1455)$ & $(0.1479)$ & $(0.1487)$ & $(0.1483)$ & $(0.3816)$ & $(0.3008)$ & $(0.3079)$ & $(0.1601)$ \\
\hline \multirow[t]{2}{*}{ growth } & $0.02480 * * *$ & $0.03015 * * *$ & $0.03003 * * *$ & $0.02985 * * *$ & $0.02505 * * *$ & $0.02480 * * *$ & $0.03015^{* * *}$ & $0.02480 * * *$ \\
\hline & $(0.00267)$ & $(0.00271)$ & $(0.00273)$ & $(0.00276)$ & $(0.00238)$ & $(0.00358)$ & $(0.00365)$ & $(0.00327)$ \\
\hline \multirow[t]{2}{*}{ btm } & $-0.7543 * * *$ & $-0.8250 * * *$ & $-0.8365 * * *$ & $-0.9012 * * *$ & 0.0567 & $-0.7543 * * *$ & $-0.8250 * * *$ & $-0.7543 * * *$ \\
\hline & $(0.0913)$ & $(0.0934)$ & $(0.0942)$ & $(0.0946)$ & $(0.1042)$ & $(0.1923)$ & $(0.2027)$ & $(0.1469)$ \\
\hline \multirow[t]{2}{*}{ constant } & $-16.056 * * *$ & $-18.887 * * *$ & $-18.082 * * *$ & $-15.686 * * *$ & $-12.285 * * *$ & $-16.056^{* * *}$ & $-18.887 * * *$ & $-16.056^{* * *}$ \\
\hline & $(1.288)$ & $(1.306)$ & $(1.311)$ & $(1.301)$ & $(3.296)$ & $(2.784)$ & $(2.816)$ & $(1.554)$ \\
\hline obs & 5,552 & 5,600 & 5,597 & 5,529 & 5,552 & 5,552 & 5,600 & 5,552 \\
\hline r-squared & 0.1795 & 0.1468 & 0.1327 & 0.1261 & 0.0743 & 0.1795 & 0.1468 & 0.1795 \\
\hline
\end{tabular}

Table 3

Impact of working capital management on return on equity (roe)

\begin{tabular}{|c|c|c|c|c|c|c|c|c|}
\hline $\begin{array}{c}\text { Dependent: } \\
\text { roe }\end{array}$ & $\begin{array}{c}\text { Pooled } \\
\text { OLS }\end{array}$ & $\begin{array}{c}\text { Pooled } \\
\text { OLS }\end{array}$ & $\begin{array}{c}\text { Pooled } \\
\text { OLS }\end{array}$ & $\begin{array}{c}\text { Pooled } \\
\text { OLS }\end{array}$ & $\begin{array}{c}\text { Fixed effect } \\
\text { model }\end{array}$ & $\begin{array}{l}\text { SE clustered } \\
\text { (by firm) }\end{array}$ & $\begin{array}{l}\text { SE clustered } \\
\text { (by firm) }\end{array}$ & $\begin{array}{l}\text { SE clustered } \\
\text { (by year) }\end{array}$ \\
\hline \multirow[t]{2}{*}{ rep } & $-0.01946^{* * *}$ & & & & $-0.01744 * * *$ & $-0.01946 * * *$ & & $-0.01946^{* * *}$ \\
\hline & $(0.00176)$ & & & & $(0.00220)$ & $(0.00310)$ & & $(0.00218)$ \\
\hline \multirow[t]{2}{*}{ icp } & $-0.00165 * *$ & & & & -0.00022 & -0.00165 & & -0.00165 \\
\hline & $(0.00074)$ & & & & $(0.00110)$ & $(0.00138)$ & & $(0.00103)$ \\
\hline \multirow[t]{2}{*}{ pdp } & $-0.00678 * * *$ & & & & $-0.00877 * * *$ & -0.00678 & & $-0.00678 *$ \\
\hline & $(0.00259)$ & & & & $(0.00308)$ & $(0.00430)$ & & $(0.00362)$ \\
\hline \multirow[t]{2}{*}{$\mathrm{ccc}$} & & $-0.00646 * * *$ & $-0.00537 * * *$ & $-0.00515 * * *$ & & & $-0.00646 * * *$ & \\
\hline & & $(0.00065)$ & $(0.00065)$ & $(0.00065)$ & & & $(0.00119)$ & \\
\hline \multirow[t]{2}{*}{ cur } & $0.4367 * * *$ & $0.5350 * * *$ & & & $0.6285 * * *$ & $0.4367 * * *$ & $0.5350 * * *$ & $0.4367 * * *$ \\
\hline & $(0.0593)$ & $(0.0592)$ & & & $(0.0850)$ & $(0.1029)$ & $(0.1074)$ & $(0.0584)$ \\
\hline \multirow[t]{2}{*}{$\mathrm{qr}$} & & & $0.4915 * * *$ & & & & & \\
\hline & & & $(0.0690)$ & & & & & \\
\hline \multirow[t]{2}{*}{ car } & & & & $0.4368 * * *$ & & & & \\
\hline & & & & $(0.0786)$ & & & & \\
\hline \multirow[t]{2}{*}{ size } & $5.1878 * * *$ & $5.4018 * * *$ & $5.3311 * * *$ & $5.0351 * * *$ & $3.7655 * * *$ & $5.1878 * * *$ & $5.4018 * * *$ & $5.1878 * * *$ \\
\hline & $(0.2977)$ & $(0.3001)$ & $(0.2999)$ & $(0.2971)$ & $(0.8197)$ & $(0.5843)$ & $(0.5744)$ & $(0.4646)$ \\
\hline \multirow[t]{2}{*}{ growth } & $0.06262 * * *$ & $0.07164 * * *$ & $0.07091 * * *$ & $0.06952 * * *$ & $0.05981 * * *$ & $0.06262 * * *$ & $0.07164 * * *$ & $0.06262 * * *$ \\
\hline & $(0.00551)$ & $(0.00554)$ & $(0.00556)$ & $(0.00556)$ & $(0.00513)$ & $(0.00732)$ & $(0.00719)$ & $(0.00777)$ \\
\hline \multirow[t]{2}{*}{ btm } & $-1.5824 * * *$ & $-1.6954 * * *$ & $-1.7395 * * *$ & $-1.8645 * * *$ & -0.0621 & $-1.5824 * * *$ & $-1.6954 * * *$ & $-1.5824 * * *$ \\
\hline & $(0.1893)$ & $(0.1916)$ & $(0.1921)$ & $(0.1917)$ & $(0.2278)$ & $(0.3892)$ & $(0.4151)$ & $(0.2259)$ \\
\hline \multirow[t]{2}{*}{ constant } & $-35.682 * * *$ & $-39.438 * * *$ & $-38.492 * * *$ & $-35.238 * * *$ & $-26.554 * * *$ & $-35.682 * * *$ & $-39.438 * * *$ & $-35.682 * * *$ \\
\hline & $(2.642)$ & $(2.656)$ & $(2.649)$ & $(2.611)$ & $(7.089)$ & $(5.415)$ & $(5.346)$ & $(4.077)$ \\
\hline obs & 5,467 & 5,518 & 5,514 & 5,451 & 5,467 & 5,467 & 5,518 & 5,467 \\
\hline r-squared & 0.1546 & 0.1388 & 0.1316 & 0.1291 & 0.0688 & 0.1546 & 0.1388 & 0.1546 \\
\hline
\end{tabular}

\subsection{Working capital management and the Tobin's $Q$}

The results of Table 4 for tests on Tobin's Q indicate largely consistent observations as we have obtained from Table 2 and Table 3. Receivables collection period and cash conversion cycle remain robust and significant negatively related to firm value proxied by Tobin's Q. For example, a day increase in cash conversion cycle is associated with about 0.0001 reduction in Tobin's $Q$, or 0.0001 times book equity and liabilities in market value. This means that a single day would cost about $\$ 100,000$ for a billiondollar firm. Efficient inventory management at lower inventory level is still found to be important given the consistent negative relationship with firm value. It is interesting to note that while a lower cash conversion cycle is preferable, it does not mean that a high payable deferral period is beneficial for 
performance. Our analysis suggests that collection period remains the most crucial working capital component that would adversely affect firm value. Liquidity ratios indicate a less consistent relationship with firm value. We find that their role has been affected by the book-to-market ratio, which has a strong correlation with Tobin's Q in nature. In our separate set of analysis without the book-to-market, liquidity ratios exhibit a very robust positive impact while the roles of receivables collection period and cash conversion cycle remain highly significant. However, we present the results with inclusion of book-tomarket ratio for the purpose of consistent comparisons across all investment indicators.

\section{Table 4}

Impact of working capital management on Tobin's Q

\begin{tabular}{|c|c|c|c|c|c|c|c|c|}
\hline $\begin{array}{l}\text { Dependent: } \\
\text { Tobin's Q }\end{array}$ & $\begin{array}{c}\text { Pooled } \\
\text { OLS }\end{array}$ & $\begin{array}{l}\text { Pooled } \\
\text { OLS }\end{array}$ & $\begin{array}{l}\text { Pooled } \\
\text { OLS }\end{array}$ & $\begin{array}{c}\text { Pooled } \\
\text { OLS }\end{array}$ & $\begin{array}{c}\text { Fixed effect } \\
\text { model }\end{array}$ & $\begin{array}{c}\text { SE clustered } \\
\text { (by firm) }\end{array}$ & $\begin{array}{l}\text { SE clustered } \\
\text { (by firm) }\end{array}$ & $\begin{array}{c}\text { SE clustered } \\
\text { (by year) }\end{array}$ \\
\hline \multirow[t]{2}{*}{$\mathrm{rcp}$} & $-0.000229 * * *$ & & & & $-0.000163 * * *$ & $-0.000229 * * *$ & & $-0.000229 * * *$ \\
\hline & $(0.000059)$ & & & & $(0.000062)$ & $(0.000082)$ & & $(0.000051)$ \\
\hline \multirow[t]{2}{*}{ icp } & $-0.000049 * *$ & & & & -0.000039 & -0.000049 & & $-0.000049 * *$ \\
\hline & $(0.000025)$ & & & & $(0.000030)$ & $(0.000030)$ & & $(0.000022)$ \\
\hline \multirow[t]{2}{*}{ pdp } & -0.000064 & & & & $0.000146^{*}$ & -0.000064 & & -0.000064 \\
\hline & $(0.000084)$ & & & & $(0.000081)$ & $(0.000103)$ & & $(0.000080)$ \\
\hline \multirow[t]{2}{*}{$\mathrm{ccc}$} & & $-0.000109 * * *$ & $-0.000116^{* * *}$ & $-0.000115 * * *$ & & & $-0.000109 * * *$ & \\
\hline & & $(0.000022)$ & $(0.000022)$ & $(0.000023)$ & & & $(0.000032)$ & \\
\hline \multirow[t]{2}{*}{ cur } & $-0.003738^{*}$ & -0.003089 & & & $0.004666^{*}$ & -0.003738 & -0.003089 & -0.003738 \\
\hline & $(0.002039)$ & $(0.002077)$ & & & $(0.002441)$ & $(0.003268)$ & $(0.003174)$ & $(0.002744)$ \\
\hline \multirow[t]{2}{*}{ qr } & & & -0.001475 & & & & & \\
\hline & & & $(0.002386)$ & & & & & \\
\hline \multirow[t]{2}{*}{ car } & & & & 0.000902 & & & & \\
\hline & & & & $(0.002749)$ & & & & \\
\hline \multirow{2}{*}{ size } & $0.1100 * * *$ & $0.1128 * * *$ & $0.1138 * * *$ & $0.1151 * * *$ & $0.0699 * * *$ & $0.1100 * * *$ & $0.1128 * * *$ & $0.1100 * * *$ \\
\hline & $(0.0099)$ & $(0.0102)$ & $(0.0102)$ & $(0.0102)$ & $(0.0229)$ & $(0.0229)$ & $(0.0232)$ & $(0.0148)$ \\
\hline \multirow[t]{2}{*}{ growth } & 0.000001 & 0.000028 & 0.000043 & 0.000053 & 0.000148 & 0.000001 & 0.000028 & 0.000001 \\
\hline & $(0.000182)$ & $(0.000186)$ & $(0.000187)$ & $(0.000190)$ & $(0.000142)$ & $(0.000172)$ & $(0.000165)$ & $(0.000179)$ \\
\hline \multirow[t]{2}{*}{ btm } & $-0.3081 * * *$ & $-0.3170 * * *$ & $-0.3162 * * *$ & $-0.3184 * * *$ & $-0.1989 * * *$ & $-0.3081 * * *$ & $-0.3170 * * *$ & $-0.3081 * * *$ \\
\hline & $(0.0063)$ & $(0.0065)$ & $(0.0065)$ & $(0.0066)$ & $(0.0063)$ & $(0.0189)$ & $(0.0208)$ & $(0.0219)$ \\
\hline \multirow[t]{2}{*}{ constant } & $0.5850 * * *$ & $0.5599 * * *$ & $0.5460 * * *$ & $0.5345 * * *$ & $0.7206^{* * *}$ & $0.5850 * * *$ & $0.5599 * * *$ & $0.5850 * * *$ \\
\hline & $(0.0880)$ & $(0.0902)$ & $(0.0898)$ & $(0.0898)$ & $(0.1973)$ & $(0.1910)$ & $(0.1956)$ & $(0.1407)$ \\
\hline obs & 5,529 & 5,579 & 5,579 & 5,509 & 5,529 & 5,529 & 5,579 & 5,529 \\
\hline r-squared & 0.3465 & 0.3414 & 0.3411 & 0.3421 & 0.1721 & 0.3465 & 0.3414 & 0.3462 \\
\hline
\end{tabular}

\subsection{Working capital management and the stock performance}

The fourth and the last investment performance indicator that we would like to compare is the stock price performance.

\section{Table 5}

Impact of working capital management on stock performance (stock)

\begin{tabular}{|c|c|c|c|c|c|c|c|c|}
\hline $\begin{array}{c}\text { Dependent: } \\
\text { stock }\end{array}$ & $\begin{array}{c}\text { Pooled } \\
\text { OLS }\end{array}$ & $\begin{array}{c}\text { Pooled } \\
\text { OLS }\end{array}$ & $\begin{array}{c}\text { Pooled } \\
\text { OLS }\end{array}$ & $\begin{array}{c}\text { Pooled } \\
\text { OLS }\end{array}$ & $\begin{array}{c}\text { Fixed effect } \\
\text { model }\end{array}$ & $\begin{array}{c}\text { SE clustered } \\
\text { (by firm) }\end{array}$ & $\begin{array}{l}\text { SE clustered } \\
\text { (by firm) }\end{array}$ & $\begin{array}{c}\text { SE clustered } \\
\text { (by year) }\end{array}$ \\
\hline \multirow[t]{2}{*}{$\mathrm{rcp}$} & $-0.000915 * * *$ & & & & $-0.000341 * * *$ & $-0.000915 * * *$ & & $-0.000915 * * *$ \\
\hline & $(0.000114)$ & & & & $(0.000092)$ & $(0.000305)$ & & $(0.000178)$ \\
\hline \multirow[t]{2}{*}{ icp } & $-0.000186 * * *$ & & & & -0.000040 & $-0.000186^{*}$ & & $-0.000186 * * *$ \\
\hline & $(0.000047)$ & & & & $(0.000045)$ & $(0.000099)$ & & $(0.000030)$ \\
\hline \multirow[t]{2}{*}{ pdp } & $-0.000528 * * *$ & & & & -0.000054 & -0.000528 & & $-0.000528 * *$ \\
\hline & $(0.000161)$ & & & & $(0.000121)$ & $(0.000363)$ & & $(0.000198)$ \\
\hline \multirow[t]{2}{*}{$\operatorname{ccc}$} & & $-0.000407 * * *$ & $-0.000340 * * *$ & $-0.000323 * * *$ & & & $-0.000407 * * *$ & \\
\hline & & $(0.000042)$ & $(0.000042)$ & $(0.000042)$ & & & $(0.000108)$ & \\
\hline \multirow[t]{2}{*}{ cur } & $0.06380 * * *$ & $0.06905^{* * *}$ & & & $0.03133 * * *$ & $0.06380 * * *$ & $0.06905^{* * *}$ & $0.06380 * * *$ \\
\hline & $(0.00383)$ & $(0.00380)$ & & & $(0.00356)$ & $(0.01041)$ & $(0.01045)$ & $(0.00419)$ \\
\hline \multirow[t]{2}{*}{$\mathrm{qr}$} & & & $0.07206^{* * *}$ & & & & & \\
\hline & & & $(0.00444)$ & & & & & \\
\hline \multirow[t]{2}{*}{ car } & & & & $0.08321 * * *$ & & & & \\
\hline & & & & $(0.00512)$ & & & & \\
\hline \multirow{2}{*}{ size } & $0.8419 * * *$ & $0.8412 * * *$ & $0.8282 * * *$ & $0.8092 * * *$ & $1.3245 * * *$ & $0.8419 * * *$ & $0.8412 * * *$ & $0.8419 * * *$ \\
\hline & $(0.0192)$ & $(0.0192)$ & $(0.0193)$ & $(0.0193)$ & $(0.0339)$ & $(0.0554)$ & $(0.0556)$ & $(0.0321)$ \\
\hline \multirow[t]{2}{*}{ growth } & $-0.000944 * * *$ & $-0.000595 *$ & -0.000560 & -0.000526 & 0.000109 & $-0.000944 * *$ & $-0.000595 *$ & $-0.000944 *$ \\
\hline & $(0.000350)$ & $(0.000349)$ & $(0.000351)$ & $(0.000356)$ & $(0.000211)$ & $(0.000380)$ & $(0.000349)$ & $(0.000450)$ \\
\hline \multirow[t]{2}{*}{ btm } & $-0.3365 * * *$ & $-0.3435 * * *$ & $-0.3433 * * *$ & $-0.3466 * * *$ & $-0.2802 * * *$ & $-0.3365 * * *$ & $-0.3435 * * *$ & $-0.3365 * * *$ \\
\hline & $(0.0120)$ & $(0.0121)$ & $(0.0121)$ & $(0.0122)$ & $(0.0093)$ & $(0.0259)$ & $(0.0268)$ & $(0.0235)$ \\
\hline \multirow[t]{2}{*}{ constant } & $-6.940 * * *$ & $-7.038 * * *$ & $-6.899 * * *$ & $-6.687 * * *$ & $-11.216^{* * *}$ & $-6.940 * * *$ & $-7.038 * * *$ & $-6.940 * * *$ \\
\hline & $(0.1700)$ & $(0.1695)$ & $(0.1697)$ & $(0.1690)$ & $(0.2924)$ & $(0.4831)$ & $(0.4863)$ & $(0.2846)$ \\
\hline obs & 5,525 & 5,576 & 5,575 & 5,504 & 5,525 & 5,525 & 5,576 & 5,525 \\
\hline r-squared & 0.3917 & 0.3828 & 0.3749 & 0.3774 & 0.3335 & 0.3917 & 0.3828 & 0.3917 \\
\hline
\end{tabular}


Table 5 further confirms the significant role of receivables collection period and cash conversion cycle in decreasing investment performance. Inventory collection period and payables deferral period still exhibit largely consistent negative signs as indicated in Tables 2-4. All liquidity ratios indicate significant and positive relationships, suggesting the importance of good liquidity position on stock price performance.

\subsection{Robustness of observations before and after the subprime crisis}

To check if the impacts of working capital components are stable across periods, we compare the results for sub periods before and after the 2007-2008 subprime crisis. The results suggest a robust role of working capital on the four investment performance indicators. Receivables collection period, cash conversion cycle and current ratio remain the most prominent and consistent in affecting investment performance both before and after the crisis. The negative effect of inventory conversion period has become more important for Tobin's Q after the crisis. However, the role of payables deferral period has faded across these two periods and become insignificant for return on equity. It is reasonable that a higher payables deferral period is not always bad in the context of cash flow management. The roles of control variables are generally robust as compared with the regressions using full period in Tables 2, 3, 4 and 5 . Firm size and book-to-market are consistently important across all indicators of performance.

Table 6

Impact of working capital management before and after the subprime crisis

\begin{tabular}{|c|c|c|c|c|c|c|c|c|}
\hline & \multicolumn{4}{|c|}{ Before crisis } & \multicolumn{4}{|c|}{ After crisis } \\
\hline & roe & roa & Tobin's Q & stock & roe & roa & Tobin's Q & stock \\
\hline \multirow[t]{2}{*}{ rep } & $-0.022955^{* * *}$ & & $-0.000134 * *$ & & $-0.019232 * * *$ & & $-0.000360 * * *$ & \\
\hline & $(0.002622)$ & & $(0.000067)$ & & $(0.002420)$ & & $(0.000108)$ & \\
\hline \multirow[t]{2}{*}{ icp } & -0.001264 & & -0.000064 & & -0.000455 & & $-0.000065 * *$ & \\
\hline & $(0.001515)$ & & $(0.000039)$ & & $(0.000740)$ & & $(0.000033)$ & \\
\hline \multirow[t]{2}{*}{ pdp } & $-0.018439 * * *$ & & 0.000039 & & 0.002519 & & -0.000160 & \\
\hline & $(0.004755)$ & & $(0.000115)$ & & $(0.002851)$ & & $(0.000127)$ & \\
\hline \multirow[t]{2}{*}{$\mathrm{ccc}$} & & $-0.005645^{* * *}$ & & $-0.000393 * * *$ & & $-0.001780 * * *$ & & $-0.000475 * * *$ \\
\hline & & $(0.000591)$ & & $(0.000073)$ & & $(0.000371)$ & & $(0.000049)$ \\
\hline \multirow[t]{2}{*}{ cur } & $0.69240 * * *$ & $0.65384 * * *$ & $0.00599 * *$ & $0.07453 * * *$ & $0.20358 * * *$ & $0.30076 * * *$ & $-0.01372 * * *$ & $0.06595 * * *$ \\
\hline & $(0.10005)$ & $(0.04599)$ & $(0.00262)$ & $(0.00574)$ & $(0.06904)$ & $(0.03711)$ & $(0.00314)$ & $(0.00498)$ \\
\hline \multirow[t]{2}{*}{ size } & $7.1847 * * *$ & $3.2068 * * *$ & $0.0873 * * *$ & $0.7316 * * *$ & $3.2609 * * *$ & $1.4927 * * *$ & $0.0913 * * *$ & $0.8657 * * *$ \\
\hline & $(0.5301)$ & $(0.2459)$ & $(0.0137)$ & $(0.0310)$ & $(0.3430)$ & $(0.1860)$ & $(0.0153)$ & $(0.0249)$ \\
\hline \multirow[t]{2}{*}{ growth } & $0.058609 * * *$ & $0.030262 * * *$ & 0.000126 & -0.000014 & $0.069115^{* * *}$ & $0.034356 * * *$ & 0.000275 & 0.000055 \\
\hline & $(0.008448)$ & $(0.003842)$ & $(0.000213)$ & $(0.000484)$ & $(0.007066)$ & $(0.003801)$ & $(0.000315)$ & $(0.000508)$ \\
\hline \multirow[t]{2}{*}{ btm } & $-1.0550 * * *$ & 0.0815 & $-0.2917 * * *$ & $-0.2742 * * *$ & $-1.9296 * * *$ & $-1.2978 * * *$ & $-0.3068 * * *$ & $-0.3600 * * *$ \\
\hline & $(0.3670)$ & $(0.1554)$ & $(0.0087)$ & $(0.0195)$ & $(0.2062)$ & $(0.1117)$ & $(0.0093)$ & $(0.0149)$ \\
\hline \multirow[t]{2}{*}{ constant } & $-53.728 * * *$ & $-25.868 * * *$ & $0.6679 * * *$ & $-6.312 * * *$ & $-17.925 * * *$ & $-8.006 * * *$ & $0.8357 * * *$ & $-7.128 * * *$ \\
\hline & $(4.569)$ & $(2.109502)$ & $(0.1176)$ & $(0.2651)$ & $(3.1251)$ & $(1.6919)$ & $(0.1399)$ & $(0.2260)$ \\
\hline obs & 2,666 & 2,759 & 2,722 & 2,743 & 2,801 & 2,850 & 2,826 & 2,847 \\
\hline r-squared & 0.1729 & 0.1627 & 0.3237 & 0.2548 & 0.1555 & 0.1401 & 0.3430 & 0.4790 \\
\hline
\end{tabular}

\subsection{Overall observations and discussion}

Based on the above results, our analysis generally suggests a robust negative relationship between cash conversion cycle components and investment returns in Malaysia post the Asian financial crisis 19971999. It is generally consistent with the findings such as by Shin and Soenen (1998), Wang (2002), Deloof (2003), Enqvist et al. (2014), Akindele and Odusina (2015), and Wasiuzzaman (2015), but opposite to the findings by Hill et al. (2012), Abuzayed (2012), Bammeri and Dehani (2013) and Nastiti et al. (2019). Out of three basic components of cash conversion cycle, receivables collection period exhibits the most prominent role in affecting returns. Long receivables period most likely reflects slow payments by customers. Negative relationship between payables deferral period and return performance is also sensible when less profitable firms are likely to delay payments. Our study suggests that account receivables shall be managed with great care, and it is not wise to simply reduce the cash conversion cycle by delaying payments to suppliers. While the main finding on cash conversion cycle is consistent with those by Eljelly (2004) and Mohammad and Saad (2010), we would like to highlight a robust finding on the 
positive role of liquidity ratios on business investment performance. We think that there are important implications due to the fact that high liquidity is usually seen as undesirable in the context of efficiency. We support that ample liquidity is vital in adding value to business returns, provided that the minimum required net trade cycle is well taken care of. Our findings indicate that the repayment abilities with or without the amounts of inventories and account receivables play the same significant role. In short, the main hypothesis pertaining to the significant relationship between working capital management and investment returns of listed firms in Bursa Malaysia is supported by our results for the period under study. Such relationship is also found to be consistent across estimations with pooled OLS, fixed effects regressions, regressions with robust standard errors clustered by firm and by time, as well as before and after the outbreak of the subprime crisis.

\section{Conclusion and recommendation}

This paper aims to provide a more updated and comprehensive empirical evidence for the role of working capital management towards business investment performance in Malaysia. Efficient cash conversion cycle management is crucial in generating positive returns for business investors. In particular, managers should pay extra attention on the receivables management as it reflects a very robust significant negative relationship towards all proxies of investment returns encompassing return on assets, return on equity, Tobin's Q and stock performance. The decrease in receivables collection period on the other hand means that the company can take shorter periods to collect payments from customers and at the same time be able to pay suppliers faster. This is especially helpful if the payables deferral period has a negative relationship with the overall investment performance of the firm. While managers could negotiate with suppliers on credit term to lengthen the payables period, such period should not be too long until it harms investment value. The good liquidity position of firm should also be maintained. The managers should generally enhance the efficiency of the cash conversion cycle of a company as it reflects a healthy operational performance. Our results suggest that the most effective way is by reducing the receivables collection period, but not lengthening the payables period. The shorter the cycle, the lesser the time capital that would be tied up in the business operations. This could reflect better ability in generating internal funds and utilising cash assets to generate more profits for investors. It would provide greater growth opportunities and raise firm's value thereafter. Based on the empirical findings, we conclude that good working capital management, in terms of efficient cash conversion cycle management and healthy liquidity position, is important in improving investment returns of businesses in the Malaysian market.

\section{References}

Abuzayed, B. (2012). Working capital management and firms' performance in emerging markets: the case of Jordan. International Journal of Managerial Finance, 8(2), 155-179.

Akindele, J., \& Odusina, O. (2015). Working capital management and firm profitability: Evidence from Nigeria quoted companies. Journal of Finance and Accounting, 6(7), 148-153.

Aktas, N., Croci, E., \& Petmezas, D. (2015). Is working capital management value-enhancing? Evidence from firm performance and investments. Journal of Corporate Finance, 30, 98-113.

Bammeri, O., \& Dehani, N. (2013). The effect of capital management on stock returns of accepted companies in Tehran Stock Exchange. European Online Journal of Natural and Social Sciences, 2(3(s)), 1061-1069.

Baños-Caballero, S., García-Teruel, P.J., \& Martínez-Solano, P. (2014). Working capital management, corporate performance, and financial constraints. Journal of Business Research, 67(3), 332-338.

Bhakoo, V., Singh, P., \& Sohal, A. (2012). Collaborative management of inventory in Australian hospital supply chains: practices and issues. Supply Chain Management: An International Journal, 17(2), 217-230.

Brush, T.H., Bromiley, P., \& Hendrickx, M. (2000). The free cash flow hypothesis for sales growth and firm performance. Strategic Management Journal, 21(4), 455-472.

Deloof, M. (2003). Does working capital management affect profitability of Belgian firms? Journal of Business Finance \& Accounting, 30(3\&4), 573-587.

Eljelly, A. (2004). Liquidity-profitability tradeoff: An empirical investigation in an emerging market. International Journal of Commerce and Management, 14(2), 48- 61. 
Enqvist, J., Graham, M., \& Nikkinen, J. (2014). The impact of working capital management on firm profitability in different business cycles: Evidence from Finland. Research in International Business and Finance, 32, 3649.

Ganesan, V. (2007). An analysis of working capital management efficiency in telecommunication equipment industry. Rivier Academic Journal, 3(2), 1-10.

Garcia-Teruel P.J., \& Martinez-Solano, P. (2007). Effects of working capital management on SME profitability. International Journal of Managerial Finance, 3(2), 164-177.

Ghodrati, H., \& Ghanbari J. (2014). A study on relationship between working capital and profitability. Management Science Letters, 4, 1675-1684.

Gunaratnam, G., \& Seela, K.C. Work your working capital. (2019, March). Retrieved from https://www.pwc.com/my/en/perspective/working-capital-management/190301-blog-wcm-work-your-working-capital.html

Hill, M.D., Kelly, G.W., \& Lockhart, G.B. (2012). Shareholder returns from supplying trade credit. Financial Management, 41(1), 255-280.

Kieschnick, R., Laplante, M., \& Moussawi, R. (2013). Working capital management and shareholders' wealth. Review of Finance, 17(5), 1827-1852.

Le, B. (2019). Working capital management and firm's valuation, profitability and risk: Evidence from a developing market. International Journal of Managerial Finance, 15(2), 191-204.

Mohamad, N.E.A.B., \& Saad, N.B.M. (2010). Working capital management: The effect of market valuation and profitability in Malaysia. International Journal of Business and Management, 5(11), 140.

Nastiti, P.K.Y., Atahau, A.D.R., \& Supramono, S. (2019). Working capital management and its influence on profitability and sustainable growth. Business: Theory and Practice, 20, 61-68.

Nguyen, H.C., Tran M.D., \& Nguyen D.T. (2016). Working capital management and firms' profitability: Evidence from Vietnam's stock exchange. International Journal of Economics and Finance, 8(5), 55-62.

Nobanee, H., Abdullatif, M., AlHajjar, M. (2011). Cash conversion cycle and firm's performance of Japanese firms. Asian Review of Accounting, 19(2), 147-156.

Lazaridis, I., \& Tryfonidis, D. (2006), Relationship between working capital management and profitability of listed companies in the Athens stock exchange. Journal of Financial Management and Analysis, 19(1), 26-35.

Padachi, K. (2006). Trends in working capital management and its impact on firms' performance: an analysis of Mauritian small manufacturing firms. International Review of Business Research Papers, 2(2), 45-58.

Raheman, A., \& Nasr, M. (2007). Working capital management and profitability-case of Pakistani firms. International Review of Business Research Paper, 3(1), 279-300.

Ramiah, V., Zhao, Y., \& Moosa, I. (2014). Working capital management during the global financial crisis: the Australian experience. Qualitative Research in Financial Markets, 6(3), 332-351.

Ray, S. (2012). Evaluating the impact of working capital management components on corporate profitability: Evidence from Indian manufacturing firms. International Journal of Economic Practices and Theories, 2(3), 127-136.

Salehi, M., Mahdavi, N., Dari, S.Z.A., \& Tarighi, H. (2019). Association between the availability of financial resources and working capital management with stock surplus returns in Iran. International Journal of Emerging Markets, 14(2), 343-361.

Şamiloğlu, F., \& Akgün, A.İ. (2016). The Relationship between working capital management and profitability: Evidence from Turkey. Business and Economics Research Journal, 7(2), 1-14.

Shin, H.H., \& Soenen, L. (1998). Efficiency of working capital and corporate profitability. Financial Practice and Education, 8(2), 37-45.

Singhania, M., \& Mehta, P. (2017). Working capital management and firms' profitability: evidence from emerging Asian countries. South Asian Journal of Business Studies, 6(1), 80-97.

Wang, Y. J. (2002). Liquidity management, operating performance, and corporate value: evidence from Japan and Taiwan. Journal of Multinational Financial Management, 12(2), 159-169.

Wasiuzzaman, S. (2015). Working capital and firm value in an emerging market. International Journal of Managerial Finance, 11(1), 60-79.

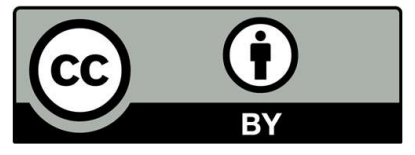

(C) 2019 by the authors; licensee Growing Science, Canada. This is an open access article distributed under the terms and conditions of the Creative Commons Attribution (CCBY) license (http://creativecommons.org/licenses/by/4.0/). 